\title{
GCU
}

Glasgow Caledonian

University

University for the Common Good

\section{Analysing the reform of the retail financial advice sector in the United Kingdom from an agencement and performativity perspective}

Ring, Patrick

Published in:

Competition and Change

DOI:

$10.1177 / 1024529415596912$

Publication date:

2015

Document Version

Author accepted manuscript

Link to publication in ResearchOnline

Citation for published version (Harvard):

Ring, P 2015, 'Analysing the reform of the retail financial advice sector in the United Kingdom from an agencement and performativity perspective', Competition and Change, vol. 19, no. 5, pp. 390-405.

https://doi.org/10.1177/1024529415596912

\section{General rights}

Copyright and moral rights for the publications made accessible in the public portal are retained by the authors and/or other copyright owners and it is a condition of accessing publications that users recognise and abide by the legal requirements associated with these rights.

Take down policy

If you believe that this document breaches copyright please view our takedown policy at https://edshare.gcu.ac.uk/id/eprint/5179 for details of how to contact us. 


\title{
Judging the success of the UK Retail Distribution Review: An agencement and performativity perspective
}

\begin{abstract}
The Retail Distribution Review (RDR) resulted in a series of reforms to the UK retail advice sector in 2012. This is the latest in a series of initiatives addressing what are identified as market failures in the UK's retail advice sector. This article uses the notions of performativity and agencement to elaborate and explain the processes by which reforms based on the economic theory of market efficiency have failed to address adequately consumer financial advice issues in the UK. The result has been a range of unresolved and unexpected problems. It is argued that the lack of success of a series of regulatory reforms intended to improve access to advice for UK consumers is destined to continue as long as the notion of market failure dominates regulatory reform.
\end{abstract}

Key words: Retail Distribution Review; agencement; performativity; regulation; advice. 


\section{Introduction}

The need for an improved advice regime in the UK's retail financial services sector has been increasingly apparent. In 2008, the UK's national savings ratio reached its lowest in nearly twenty years (ONS, 2010), and it is predicted savings levels will continue to be amongst the lowest in the OECD countries (OECD, 2014). At the same time, poor levels of literacy and numeracy, and individuals' lack of confidence in their own financial abilities (Atkinson et al. 206; Clery et al., 2010; House of Commons Public Accounts Committee, 2009), have underlined the importance of advice and support for individuals in making decisions about their financial future.

Yet, there is lack of trust in financial firms (Chartered Insurance Institute, 2010; Edelman, 2012). A range of costly and highly publicised advice scandals, including personal pensions, endowment mortgages, 'precipice' bonds and, most recently, Payment Protection Insurance (PPI) (Dunn, 2009; Goff \& Cadman, 2014) illustrate problems in the advice sector, including complexity, bias, lack of consumer capability and poor quality of advice. The UK financial regulator has noted that:

Taken together, these features suggest that the market for retail investments does not work efficiently - and certainly not as well as it could - serving neither the interests of consumers or firms, whether providers or distributors of retail financial services. (FSA, 2007:4)

It is no wonder the regulation of retail financial advice in the UK has undergone significant examination and reform, most recently as a result of the Retail Distribution Review (RDR) (see FSA, 2009a). The RDR has resulted in a series of reforms concerning the provision of financial advice that were implemented fully by the end of 2012. As the regulator has stated:

... the Retail Distribution Review (RDR) is one of the core strands of our retail market strategy. It complements our aims to improve financial capability and further ensures firms deliver fair outcomes for consumers. It is essential for promoting a resilient, effective and attractive retail investment market. The RDR will modernise the industry, giving more consumers confidence and trust in the market at a time when they need more help and advice with their retirement and savings planning. (FSA, 2008a:3 
The various policy strands arising from the RDR, like reforms dating at least as far back as depolarisation reforms in 1988, are concerned with improving market efficiency, addressing market failures to achieve better outcomes for consumers in the retail advice market (Ring, 2004). They are underpinned by a model of ideal markets, efficiency and market failures. The assumption is that addressing market failures will improve overall welfare in the (retail advice) market (Dasgupta, 2007; Moore, 2007).

This article therefore takes its starting point from the initial analysis set out in the Review itself:

\begin{abstract}
A principal aim of regulation is to deal with market failures. These have manifested themselves in various ways in the distribution of retail investment products. We are using this review to address these issues with a view to improving the working of the market and thereby reduce the need for regulation. (FSA, 2007:15)
\end{abstract}

Recent research has drawn tentative conclusions about the extent to which the reforms arising from the RDR will improve access to, as well as the cost of, advice. It has also identified potential problems that still require to be overcome (see, for example, Clare, 2013; The Personal Finance Society, 2014). More generally, Georgosouli (2007) notes the limitations of using an economic rationale to develop policy in relation to investor protection, highlighting both the technical and socio-political shortcomings of an economic rationale for regulatory reform.

The article therefore provides a critique of current financial regulation in the UK retail advice sector. In particular, it draws attention to one approach for tracing the processes and mechanisms through which the outcomes of regulatory reform can be understood. In doing so, it argues that the theory of market efficiency underpinning the reforms in retail advice can be understood as being performative. It also argues that this theory is an integral element of a collection and framing of statements, behaviours and material practices, assembled to 'perform' the very circumstances that theory purports to describe (Callon 2006). 
Here, Callon's idea of agencement is useful in re-envisaging the RDR as a 'framing and attribution' device (Callon, 2005). By agencement, what is meant is any collection of actors, equipment, texts, technical devices or tools which, by their interconnection, give rise, and meaning, to action (Muniesa et al., 2007; Mackenzie et al., 2007). The trajectory of the retail advice sector therefore depends upon the actions and outcomes arising out of the collection, or assemblage, of day-to-day relationships, procedures, processes, economic theory and material devices arranged through the agencement of the RDR.

It is important to recognise that this approach rejects the notion of economic theory as an attempt to delineate the 'nature' of some kind of 'natural phenomenon'. Instead, the performative function of the theory of efficient markets and market failure arises through it both purporting to describe, as well as attempting to constitute (through the agencement of which it forms part), the nature of those markets. In that sense, the success of the RDR depends upon the extent to which the theory of efficient markets, and its consequences, come to be regarded as encapsulating the 'truth' (Callon, 2006:14). This article argues that continuing problems in the reform of the retail advice sector, provide evidence of what has been referred to as 'counter-performativity' (Mackenzie, 2006). In attempting to encapsulate the 'reality' of the advice sector through an economic assemblage, the actions and outcomes of that assemblage have created unintended and unanticipated problems that result in the 'reality' becoming less like the theory. The latest concerns over RDR are simply the current manifestation of this saga that has played out over decades.

The discussion begins by examining regulatory developments in UK retail advice over the past decade. It then analyses these developments using the notions of agencement and performativity, considering the extent to which the economic theory of market efficiency can be said to be performative. Thereafter, consideration is given to the problems and issues that have arisen in the course of the RDR and to how these represent examples of counterperformativity, the unexpected and unanticipated events that arise in the attempted performation of market efficiency in the context of an 
economic agencement. It is suggested that, at least in part, this can be attributed to the inherent difficulties in adopting an economic approach to the retail advice market.

\section{Retail advice and regulation in the UK}

From 1988-2004 consumers in the UK retail advice market sought advice either from a 'tied' adviser or an independent financial adviser (IFA). The former was an agent of one particular company providing retail financial products, and could only advise on the products of that company. The latter was an agent of the customer and advised on products across the market of providers. This arrangement was referred to as 'polarisation'.

The Director General of Fair Trading (DGFT), illustrating the pervasive influence of the notion of market efficiency, noted that 'the polarisation rules restrict or distort competition to a significant extent' (OFT, 1999:10), but were justified in order to protect consumers. This reflected the view that 'in efficient markets, the preferences of the end-consumer will ultimately drive behaviour and market structure', but that the retail financial services market was one of 'weak consumer influence’ (Sandler 2001:7).

In November 2000 the Financial Services Authority (FSA) sought reform of polarisation, arguing consumer weaknesses could be addressed 'through other methods which we expect to be much less restrictive of competition' (Davies, 2000). A continued emphasis on market efficiency was reflected in the titles of its two key Consultation Articles: CP121, 'Reforming Polarisation: Making the market work for consumers' (FSA, 2002a); and CP166, 'Reforming Polarisation: removing the barriers to choice' (FSA, 2003). It was argued customers did not shop around for advice in the polarised regime, thereby creating 'vertical restraint' in relying on the brand name of a provider (through its tied advisers) rather than a relatively unknown IFA. Effectively, this gave customers a choice of only one firm’s products (FSA, 2002a:46).

This focus on market efficiency is reflected across the recent history of the UK financial regulator. When the FSA was given statutory objectives in 2000, a key aspect of its 
work was been to improve consumer outcomes. In the retail financial advice market, the underlying philosophy was been to increase market efficiency by addressing market failures. The very first Occasional Article published by the FSA in 1999 was 'The Economic Rationale for Financial Regulation’ in which seven economic justifications for regulation were identified (Llewellyn, 1999). These were grouped around what are generally regarded as the key justifications for efficiency-enhancing interventions in the market: information asymmetries; monopolies, or more generally lack of competition; and externalities (Backhaus, 2012; Wonderling, 2005). It is an approach which has been continued by the FSA's successor, the Financial Conduct Authority (FCA), since 2013.

It was in this context that, in 2004, 'depolarisation' reforms were introduced. These reforms created an additional third category of adviser firm - one which could 'multitie' to a limited number of providers. It was argued that even if consumers did not shop around, using a multi-tied adviser provided greater choice. It also created competition amongst product providers to tie with these multi-tie firms. The reforms also included enhanced disclosure of information by product providers so that consumers could exercise greater influence in the market by being more aware of the choices available to them. In addition, advisers were required to offer clients the opportunity to pay by fee if they wished to be regarded as independent. This last reform was based on evidence suggesting consumers regarded 'independent' advice as advice that is not influenced by the amount of commission an adviser receives from a product provider (FSA, 2002b:1820). The idea was to avoid any suspicion of commission bias in adviser recommendations.

Yet, by 2007 the FSA had returned again to the issue of market efficiency, announcing that:

there are features associated with the distribution of retail investment products that result in inefficiencies for the market and poor outcomes for consumers. This is despite intensive regulation in this area for nearly two decades. (FSA, 2007:12) 
It noted that, despite previous significant reforms, 'The market for the distribution of retail investment products is characterised by a number of market failures' (FSA, 2007:15). These failures centred around three key concerns: complexity of products and charges; lack of consumer experience and knowledge; and the potential for the first two concerns to lead to consumer detriment as a result of any misalignment of interests between advisers and their clients. It also noted two further issues linked to market failures: the cost of advice, leading to poorer access for consumers; and the relatively low level of qualification required for financial advisers. It was suggested the latter might help explain both poor consumer outcomes and lack of trust in financial advisers.

Thus was the start of the RDR. By $31^{\text {st }}$ December 2012, when a series of reforms were introduced and implemented, the regulator had produced 18 Consultation Papers, 5 Discussion Papers, 15 Policy Statements and 17 separate pieces of research (FSA, 2015). Whilst it is not possible to provide a chronicle of these developments in this discussion, it is important to highlight three key elements that formed the basis of the reforms. Firstly, advisers are categorised as providing a service which is either 'independent', taken to mean unbiased, unrestricted advice based on a comprehensive and fair analysis of the relevant market; or restricted, being any advice which is not independent. The aim is to provide greater clarity for consumers. Firms are required to disclose in writing to each client which service they will provide (FSA, 2009a).

Secondly, payment by commission is banned and adviser firms can only be remunerated by 'adviser charges', agreed with the client at the start of the advice process. The aim is 'to reduce the potential for remuneration to influence adviser recommendations, directly or indirectly' (FSA, 2009a:23). Thirdly, to 'deliver standards of professionalism that inspire consumer confidence and build trust' (FSA, 2009a:40) advisers must attain a higher level of basic qualification than previously required, complete mandatory annual CPD requirements, and sign up to a Code of Ethics as part of membership of a recognised professional body.

In addition, the FSA set out its thinking on 'simplified advice' - more streamlined processes enabling advice to be delivered in a more cost-efficient (and therefore 
cheaper) manner in limited and less complex advisory situations. Although the same requirements regarding charging, disclosure of status and professionalism must apply, the aim is to try and overcome 'gaps' that might arise as a result of the costs of 'full' RDR-compliant financial advice excluding some consumers who may be unable or unwilling to pay the charges for independent or restricted advice (Clare, 2013).

In summary, the history of recent reforms in the UK retail advice sector, spurred on by the RDR, has been one of attempts to address lack of competition in the market (for example, addressing 'vertical restraints' through multi-tie advisers); to address what are considered to be information asymmetries arising from the complexity of financial products and charges (for example, through greater, and simpler, disclosure of information about both the advice service provided and products recommended); and to address externalities, such as lack of trust caused by financial scandals (for example, by addressing issues of potential bias and professionalism).

\section{Performativity and agencement in the reform of retail advice}

Foucault argued that in order to understand agency what is required is not a theory of the subject, but a theory of discursive practice (Foucault, 1970). Networks of knowledges, controls and resistances are linked in a discursive practice of disciplinary regimes, and particularly through repeated performances of 'technologies of the self' (Dean, 1996; Redman, 2000:10). An adequate conception of agency and the agent only comes through examining the performance of these discursive practices.

The notion of discursive development of identity is also taken up by Butler, who uses performativity as a means of understanding how the 'self' is constituted. For Butler, commonly held discourses concerning 'gender' can be created, sustained or undermined through performance. In this sense, performance can enable agency - performativity is not an act of description, but constitution of the self through an act of description. At the same time, continuous acts of performance take place within a pre-existing (self-) 'regulatory' frame. To understand the performative nature of these acts, it is important therefore to trace performance within an existing set of norms or conventions, and how 
all of this comes to be incorporated into individual subject positions. This also draws attention to the relevance of context - that the possibilities of performativity, of agency, are dependent upon the network of connections, relations and resources that can be drawn upon and integrated into the act of performance (Butler, 1993). The importance of connections is also emphasised by Deleuze and Guattari (1987) who draw attention to the importance of the piecing together (they use the term agencent), or assembling, of elements to understand the importance of multiplicity in the origins of behaviour and ideas.

The notion of 'assemblages' is taken up by Callon, who uses this as a means of drawing attention to the manner in which interconnected elements have a capacity both to act (agency) and give meaning to that agency. A significant aspect of the work of Callon, therefore, is in drawing our attention to market devices, agencements, connected through material and discursive practice (Callon et al., 2006). Importantly for the present discussion, these assemblages are performative, being the collection of human, technical, material and social elements from which performance springs, and in turn from which 'markets' and market actors are constructed and understood. (Muniesa et al. 2006). In turn, this obliges us to not take markets and market behaviour for granted as some form of natural phenomena, nor the theories underpinning them as simply the description of such phenomena. Rather, it is necessary to explore the manner in which market architectures, and the rights and obligations within those architectures, are constructed.

In the present context, characterising the issues facing retail financial services in terms of market efficiency comes from the epistemic domain of economics. Neoclassical economics claims a perfectly competitive market allocates resources optimally, relying upon the rationality of the market participants, the availability of the appropriate information, and the laws of supply and demand. This latter element assumes voluntary exchange between market participants, with full information, creating maximum benefit for both buyers and sellers. To the extent that problems exist in securing this normative 'ideal' state, it is argued that any 'failures' in a market can be addressed. This may involve improving the ability of the participants to behave 'rationally', increasing the 
availability of market information, or addressing issues that might otherwise 'block' the natural supply of, or demand for, a product.

For Callon, such a theory becomes performative 'if it contributes to the construction of the reality that it describes' (2006, p.7). It must be able to systematically incorporate the phenomena, events, the data over which it claims to have epistemic authority, such that what results is the state referenced by the theory (see Preda, 2007). Callon identifies the importance of understanding the 'relationships between statements and their worlds as socio-technical agencements....... the idea of a combination of heterogeneous elements that have been carefully adjusted to one another' (Callon, 2006, p.13). This assemblage of elements interacts to create the conditions enunciated by theoretical statements. It is in this context that we might refer to RDR as a sociotechnical agencement.

Here, as well as theory itself, we need to take account of technology, systems and tools - 'market devices' (Callon et al., 2006) - as elements of an agencement. Thus, addressing market failure in the UK advice sector is increasingly associated with developments in internet solutions, mobile 'apps', planning tools, and interactive financial models to 'transform' individuals into putative 'life planners' (Fowler, 2011). At the same time, adviser and provider use of electronic 'platforms', creating an everwidening choice of investments and the tools to manage them, have become commonplace (Clare et al., 2013). These are incorporated into the advice process as a means of overcoming market failures such as 'information asymmetries' created by the 'principal/agent' problem.

\section{Performation in action}

It is submitted that such developments illustrate Mackenzie's notion of 'generic' performativity; where 'an aspect of economics ......is used, not just by academic economists, but in the 'real world"' (MacKenzie, 2006: 16-18). In that context, the provision of retail financial advice in the UK is understood as a 'market', suffering 'failures' that need to be addressed to produce more 'efficient' outcomes. This is, 
broadly speaking, a commonplace notion within the financial services industry, amongst commentators and market participants. It is also a fundamental assertion of the UK regulator.

We can also witness 'effective' performativity; that is, 'a process involving use of the aspect of economics in question differs in some significant way ..... from what would take place if economics was not used.' (MacKenzie, 2006:18). MacKenzie (2006) points out that the difficulty of not being able to carry out a 'with'/'without' comparison means this issue is often one of judgement or conjecture. That said, it is possible to distinguish several strands of development in the UK advice sector which are neither inevitable nor obvious in their trajectory or outcome, and which suggest it is possible to delineate evidence of effective performativity.

The idea of information asymmetries, market failures arising from consumers lacking information or understanding products or processes, suggests it is possible to make individuals more 'effective' consumers by providing them with more information, better and more widespread financial education (Personal Financial Education Group, 2013a and 2013b) or making processes simpler (Sandler, 2001). This goes further than providing a better service to consumers to gain custom, or taking advantage of new technology to improve the provision of services and products. Individuals must be provided with specific information in very specific formats and at specific times (see FCA Conduct of Business Sourcebook (2015)). Even absent such requirements, advisers are provided with suggestions of 'good' and 'bad' practice in providing information and support (FCA, 2013a). Financial education is now integrated into school curricula, and significant efforts are being devoted to 'guiding' financial consumers (Personal Finance Education Group, 2013b; the Money Advice Service, 2011). As well as providing evidence of the incorporation of economic market theory into the infrastructure of financial advice (MacKenzie, 2006), it might be argued that what we see here is the development, more or less tentatively (see FSA, 2008b), of the boundaries of a notion of the consumer as 'responsible investor'. 
RDR's incorporation of the need to address market failures and externalities, and thus increase competition, has resulted in a significant 'remodelling' of retail financial consumers as well as the financial advice 'market'. The abolition of commission, categorisation of advisers as either 'independent' or restricted', and requirements concerning higher qualifications and ongoing professionalism, have not been inevitabilities, as witnessed by debates throughout the reform process. They have, nevertheless, brought significant changes to the advice models and practices of financial firms and advisers, as well as to products, advice and charging models and general practices of both advisers and providers of financial services (Clare et al., 2013; Fowler, 2011; Fundscape, 2014).

Reforms concerning professionalism, again underpinned by the need to address market failures, have enhanced the role and reach of professional bodies in developing an appropriate qualifications framework, as well as the monitoring of standards and ethics (FSA, 2009b). This was not the only route available to the regulator (FSA, 2009b and 2010), but it is one that has been grasped with both hands by professional bodies (see, for example, CII, 2011 and CISI, 2012). Having established themselves as ethical guardians, this has had very specific implications for the behaviours and businesses of those who must now publicly commit themselves to professional body codes of conduct and ethics. Again this suggests effective performativity - that the process and outcomes have differed from what might have taken place if the underpinning rationale of market efficiency had not been present.

What makes performation possible is the socio-technical agencement which 'ties together all these scattered elements into a chain in which they are all indissociably linked. One is forced to go through them just as if a line of reasoning was being unfolded, a system developed or a law applied.' (Callon \& Latour, 1981:289). It is in this spatio-temporal frame that the notions of market efficiency and failure 'function', that performation takes place (Callon, 2006). The theory of market efficiency is not a mirror reflecting some knowable configuration, offering the opportunity to perform a slight adjustment in the mirror's gaze. The agencement 'performed' in the RDR is the means by which 'market efficiency' has real effects on the retail advice sector. It 
insinuates itself into the language used to constitute that 'market'. 'Market failures' are addressed in a way that results in less 'imperfect' information, fewer 'externalities', and reductions in 'imbalances' of power or 'barriers' to entry. Consumers are 'empowered' to address the 'principal/agent' problem. The delivery of advice is altered to reduce 'restraints' and 'biases'. The resulting claims of greater 'efficiency' draw upon the positive connotations of 'efficiency' to assert legitimation for the very reforms they laud (Mackenzie, 2006; Henriksen, 2013).

Judging the success of the reforms in the retail advice market therefore becomes an assessment of the extent to which performation takes place through the sociotechnical agencement of the RDR. It is an evaluation of the extent to which an 'efficient market' in financial services is constituted through acts understood as 'performances' of the theory of market efficiency.

\section{A retail advice sector in performance - the difficulties for RDR}

If 'the success or failure of the performation ....... is the realization of the sociotechnical agencement inscribed in the statement' (2006, p.18), then it is not obvious that the RDR has acted to create an advice sector where consumers and advisers function as efficient market participants. Rather, examining the landscape of the retail advice sector reforms reveals what Mackenzie (2007) calls 'counterperformativity'. That is, the deployment of the theory of market efficiency may, in some respects, have made things less 'efficient'. This may be as a result of what Callon refers to as 'overflowing', where 'the fact of imposing devices designed to realize a statement causes other worlds to proliferate in reaction to that performation' (2006, pp.17-18). He argues:

The history of science is nothing but the long and interminable series of untimely overflowings, of socio-technical agencements that have been caught out, unable to discipline and frame the entities that they assemble. (Callon, 2006:17-18) 
In the case of the RDR, several examples of its unintended, or unanticipated, consequences illustrate this argument.

\section{Confusion: advisers and advice}

The past decade has brought three different definitions of 'independent' advice, two different definitions of 'tied' advice (subsequently scrapped as a category of advice altogether), and the introduction of 'multi-tied' advice - then removed and replaced by the notion of 'restricted' advice. Consumers were confused and misled under the depolarised regime (Bamford, 2006; FSA, 2006), and under recent reforms the scope for confusion and lack of transparency has actually increased (Fowler, 2011; FCA 2013b). The notion of financial advice, even restricting oneself to terminology used by the regulator, now includes 'regulated' advice, 'independent' advice, 'restricted advice', 'focused' advice, 'simplified' advice, 'basic' advice and 'generic' advice (Hurman \& Costain, 2012; FCA, 2014a). In some cases, descriptions of advice appear to be being used in a misleading way (Reichman, 2014); and even industry participants have sought further clarification on what the definitions mean in practice (FCA, 2014a).

At the same time, Government policy has seen the promotion of 'guidance', regarded as something that falls short of regulated advice (FCA, 2014a). This has created debate and confusion about the distinction between guidance and advice (Hamilton, 2014). It is compounded by the main provider of guidance in the UK refers to this as its 'own free and impartial advice service ${ }^{5}$ (the Money Advice Service, 2014) and the two main providers delivering a Government guarantee of pension guidance being The Pensions Advisory Service and the Citizens Advice Bureau (Cumbo, 2014).

The result is that attempts to provide clarity and reduce information asymmetries and adviser bias have resulted in greater confusion. At the same time, the capability of the $\mathrm{RDR}$, with its rationale of market efficiency, to meet the range of needs and desires evident in those seeking security through investment in financial products, has been called into question (Clare et al., 2013; Fowler, 2011; Hurman \& Costain, 2012). 
The advice gap and the DIY investor

The RDR reforms are creating an advice 'gap' as a result of millions of individuals either being unwilling to pay for advice, or not having sufficient investable assets to be profitable for advisers (Clare, 2013; Fowler, 2011; Hurman \& Costain, 2012). Despite attempts to encourage more cost-effective models for 'simpler' advice situations, the application of 'full advice' standards to such 'simplified' models is problematic for advisers (FCA, 2014a). There is a reluctance to engage in simpler, automated processes which might enable advice to be delivered more cheaply to a wider range of clients, but which advisers fear could be judged by the advice standards applied to individual consultations with a qualified financial adviser (FCA, 2014b).

Partly as a consequence of these developments, there is a growing prevalence of 'DIY' investors (Deloitte, 2012; Fundscape, 2014). Using a range of, often interactive, media and applications, and taking advantage of the latest technology in web-based platforms (Fundscape, 2014), some firms have exploited the advice 'gap' to attract and manage investment funds by enabling financial decisions to be made by individual consumers using support and guidance (but not 'advice') provided by those firms. This brings with it the danger of 'guidance' (as opposed to advice for which a firm or adviser takes responsibility) motivating individuals to make partially informed or understood decisions (Fowler, 2011; NMG Consulting, 2014). Whilst the proliferation of software and interactive media has made it easier for individuals to arrive at 'guided' decisions themselves, there is evidence to suggest some may perceive this assistance as advice, and that a significant minority still end up making decisions harmful to their financial security (Hurman \& Costain, 2012; NMG Consulting, 2014).

Again, we find what can be regarded as 'overflowing' (Callon, 2006). The actions and outcomes emerging from the RDR have created dubiety over what may be understood as 'advice' in the retail investment market, both amongst advisers and consumers. At the same time, confusion over the status of 'guidance' creates opportunities for misunderstandings and potential problems. Indeed, the advice 'gap', and increasing prevalence of less formal forms of assistance, call into question the extent to which the 
notion of a market adequately articulates the experience of individual financial services consumers. Characterising this as a domain where market failures have been addressed and consumers can, or can be enabled to, overcome the remaining information asymmetries or other inefficiencies in retail financial services markets, becomes more difficult to maintain.

\section{Capability of consumers}

This last point highlights a further concern over the ability of individuals asked to make, sometimes complex, investment decisions. The wealthy are likely to be more financially capable (Atkinson et al., 2006; Department for Business, Innovation and Skills, 2013) as well as being more able to afford financial advice. By contrast, the complicated nature of financial services, alongside lack of financial capability, are key issues for the less well off (FSA, 2003; Atkinson et al., 2006). In part, this is due to relatively low levels of literacy and numeracy (Department for Business, Innovation and Skills, 2013; OECD, 2013). With general numeracy declining in recent years, around 80per cent of adults in the UK have low levels of numeracy (National Numeracy, 2014). Indeed, one national survey found that 16per cent of those surveyed could not identify the balance on a bank statement (the Money Advice Service, 2013).

It is not surprising, therefore, that individuals generally express low levels of confidence in their financial abilities (Clery et al., 2007 and 2010) and that evidence suggests that retail investors experience significant levels of confusion and uncertainty (Webb et al., 2014). It might be argued that financial skills can improve with experience, and that the issue is as much about engagement as it is about capability (Selnow, 2004). However, recent research suggests those currently 'not engaged' with the financial services industry, that is non-investors, comprise over 50per cent of the adult population. For individuals with investment and savings products, the same research also suggests that only around one fifth have a good understanding of the products they hold (Clare, 2013). 
In the case of pensions saving, the UK government has responded by introducing automatic enrolment - a process whereby employers automatically enrol employees into pension schemes and deduct contributions from their wages (although employees have the right to opt out). This attempts to overcome lack of financial knowledge or engagement by exploiting predictable consumer heuristics, in this case inertia, as a means of altering financial behaviour (see, for example, Dixon, 2006; Elliott et al., 2011; Thaler \& Sunstein, 2008). It is argued that inertia (lack of engagement) will result in employees remaining in the pension scheme and, through its default mechanism, continuing to make private retirement provision.

Yet, this calls into question any approach based on market failure, and attempts to 'remedy' lack of financial awareness or ability when millions are now being enlisted as pension investors and becoming financial 'consumers' without the need to be engaged in, or understand, the investment market at all.

\section{RDR and its difficulties - a case of counterperformation}

It is submitted that the effectiveness of the RDR as an agencement lies in the ability of the theory of market efficiency to be performative; firstly, to 'disentangle' the socioeconomic complexity of the lives of individuals, as well as the multi-faceted nature and role of a financial services industry in a modern society; and secondly, to assemble various elements from within that complexity to produce action and outcomes that resolve the complexity through addressing market failures and increasing market efficiency (see Callon, 2006). In this way, fundamental and overlapping questions concerning individual financial security, the role and responsibilities of the financial services industry in the lives of individuals, the inherent risks in financial transactions, and the role of the state in ensuring social protection (in particular pensions and health), are understood and addressed through a very specific prism.

This requires very particular forms of action and outcomes. It requires ethical and professionalised advisers whose role is now to assist financial consumers in achieving good outcomes for themselves. It demands action re-modelling the provision of advice, 
as well as products and their charging structures, to become clear and transparent for those seeking advice (FCA, 2013a). It also involves 'empowered' individuals acting on the basis of appropriate guidance, information and education. This reduces information asymmetries and makes those individuals capable of shouldering the responsibilities they have as financial consumers to seek out (and understand) information and to take and understand advice, as appropriate, to ensure their own financial security in retirement. As Callon puts it:

performative programs of economics tend to localize agencies in (individual) human corporeal envelopes and to equip them with tools, instruments, prostheses .... and rights, enabling them to construct something like individual interests (likened to income, indexes of satisfaction or welfare, or degrees of recognition of their legitimate dignity), and granting them the resources to calculate them. (Callon, 2006, p.45)

Individuals seeking financial well-being can be assisted, where necessary, to become calculating investors (Ring, 2010), equipped with an increasing range of 'enabling' technical tools, information sources and prompts to assist them in fulfilling this role. Well-being is now capable of being delivered through an increasingly commodified and transparent advice process. Advice, guidance and 'simplified' advice can be defined, packaged and delivered to suitably empowered consumers. It is the 'agency' of RDR, the assemblage of tools, systems, processes, texts, actors and equipment, that 'acts' to bring this about.

Yet, as we have seen, there is dubiety about what constitutes advice; about the dividing line between advice and guidance, as well as the difference between independent and restricted advice. This is already leading to confusion and potential detriment. In addition, the ability of individuals to access professional financial advice has diminished, and there remains doubt about the potential availability of less intensive 'simplified' advice. Many are still confused by financial products, despite efforts to promote financial education and awareness. As a result, many more individuals have become 'DIY' investors in the absence of viable alternatives and in the face of (for many) a relative lack of financial capability. 
The agencement of RDR, in producing actions and outcomes that appear to undermine the RDR itself, exhibits counterperformativity. It is an example of 'socio-technical agencements that have been caught out, unable to discipline and frame the entities that they assemble’ (Callon, 2006:18).

\section{Conclusion}

The introduction of the RDR is the latest in a line of reforms addressing what are considered to be market failures in the retail financial services. It represents a significant set of reforms, and as a result its potential to deliver successful outcomes has been the subject of much discussion.

While it might be considered as very early to make definitive judgements, it can be argued that what is clear is that the RDR has resulted in an 'advice gap'. At the same time, the structure of the reforms makes it difficult to deliver the kind of 'simplified advice' which many believe is necessary to address the gap. This has already resulted in further consultation and dialogue from the regulator as it attempts to adjust, or at least clarify, the nature of the reforms in order to deliver the consumer outcomes intended (FCA, 2014a).

Yet, the analysis in this article suggests that the problems are more deep-seated. Based particularly upon the work of Callon concerning performativity and agencement, it has been argued that the RDR has been undermined by a fundamental difficulty arising from its own basic logic. Specifically, there are problems with the notion that retail financial services should be understood in terms of a 'market' that can be made to work 'efficiently' to produce optimal welfare outcomes for individual savers, and that the nature and conduct of advisers and individuals can be shaped to enable this to happen. Here, we return to Callon's observation that:

The history of science is nothing but the long and interminable series of untimely overflowings, of socio-technical agencements that have been caught out, unable to discipline and frame the entities that they assemble. (Callon, 2006, pp.17-18) 
The regulator's attempt to create an 'efficient market' in retail financial services can be likened to an attempt to push air out of a partially inflated balloon. As one set of problems are pressed down on, another set of problems pop up elsewhere. On each occasion, as the notion of market efficiency works within an assemblage of individuals, institutions, tools, processes, devices and procedures to constitute its own 'reality', further problems or 'inefficiencies' arise. This should not be surprising. As a simple starting point, there are broader issues, including psychological and ontological security, and collective and individual social needs and biographies, which we would need to incorporate into any comprehensive analysis or understanding of the relationship of individuals and financial institutions in a modern economy. As has been suggested by Sandel, not all human behaviour can be understood as market behaviour; nor can social relations be re-made in the image of market relations (Sandel, 2012).

Observing the problems and shortcomings of an economic approach to the regulation of financial services is not new (see Georgosouli, 2007). However, the significance of this discussion is in drawing attention to the processes by which action and outcomes in the sphere of financial advice have arisen. The notion of agencement enables a tracing of the actions and outcomes in recent reform of the UK's retail advice sector, suggesting that the experience has been one of performation and counterperformation. This analysis of the RDR suggests that, in the context of UK retail financial advice, we should brace ourselves for further unintended consequences and further reforms. 
Atkinson, A, McKay, SD, Kempson, HE and Collard, SB. (2006) Levels of financial capability in the UK: results of a baseline survey (Consumer Research 47). Financial Services Authority.

Backhaus, J.G.(ed.) (2012) Handbook of the History of Economic Thought: Insights on the Founders of Modern Economics. London. Springer

Bamford, M. (2006) The public is very confused. IFAOnline. Available at: http://www.professionaladviser.com/ifaonline/opinion/1348116/the-public-confused [Accessed 13th July, 2007]

Butler, J. P. (1993) Bodies that matter: on the discursive limits of "sex". New York. Routledge.

Callon, M. (2005) Why Virtualism Paves the Way to Political Impotence: A Reply to Daniel Miller's Critique of The Laws of Markets. Economic Sociology: European Electronic Newsletter, Vol.6 No.2 (February):3-20

Callon, M. (2006) What does it mean to say that economics is performative? CSI Working Article Series No.005, 2006. Availaible at: http://halshs.archivesouvertes.fr/docs/00/09/15/96/PDF/WP_CSI_005.pdf [Accessed 11th April, 2014]

Callon, M. and B. Latour (1981). Unscrewing the Big Leviathan: how actors macrostructure reality and how sociologists help them to do so. In K. D. Knorr-Cetina and A. V. Cicourel (Eds.) Advances in Social Theory and Methodology: Toward an Integration of Micro- and Macro-Sociologies. Boston, Mass, Routledge and Kegan Paul

Callon, M., Millo, Y. and Muniesa, F. (eds.) (2007) Market Devices. Oxford. Blackwell Publishing Ltd.

CII (Chartered Insurance Institute). (2010) What we talk about when we talk about trust: The future of trust in insurance and financial services. London. Chartered Insurance Institute

CII (Chartered Insurance Institute). (2011) PROFESSIONALISM FOR THE 21ST CENTURY - REVISITED. Articles in Professionalism 10. London. Chartered Insurance Institute

CISI (Chartered Institute for Securities and Investment) (2012) CISI introduces mandatory integrity and ethics testing for members. Press Release, $28^{\text {th }}$ March, 2012. Available at: http://www.cisi.org/bookmark/genericform.aspx?form=29848780\&url=80134336 [Accessed $7^{\text {th }}$ July, 2014]

Clare, A. (2013) The Guidance Gap: An investigation of the UK's post-RDR savings and investment landscape. London. FIL Investment International

Clare, A., Thomas, S., Walgama, O. and Makris, C. (2013) The impact of the RDR on the UK's market for financial advice: Challenge and opportunity. June 2013. CASS Consulting. CASS Business School. Available at: http://www.cass.city.ac.uk/_data/assets/pdf_file/0016/202336/The-impact-of-RDRCass-version.pdf [Accessed 7th July, 2014]

Clery, E., Mckay, S., Phillips, M. And Robinson, C. (2007) Attitudes to pensions: The 2006 survey, Research Report No.434, Leeds, Department for Work and Pensions 
Clery, E., Humphrey, A., and Bourne, T. (2010) Attitudes to pensions: The 2009 survey, Research Report No. 701, London, Department of Work and Pensions

Cumbo, J. (2014) Citizens Advice and TPAS to provide pension guidance. Financial Times.18 ${ }^{\text {th }}$ October 2014. Available at: http://www.ft.com/cms/s/0/78c2be74-561e11e4-93b3-00144feab7de.html\#axzz3KdM7HcPp [Accessed $11^{\text {th }}$ November 2014]

Dasgupta, P. (2007) Economics: A Very Short Introduction. New York. Oxford University Press.

Davies, H. (2000) Open Letter from Howard Davies to The Chancellor of the Exchequer dates $1^{\text {st }}$ November 2000. Available at: http://www.fsa.gov.uk/pubs/press/2000/135_letter.pdf [Accessed 7th June, 2014]

Dean, M. (1996). Putting the technological into government, History of the Human Sciences, Vol.9 (No.3) 47-68.

Deleuze, G. and Guattari, F. (1987) A thousand plateaus: capitalism and schizophrenia. Minneapolis. University of Minnesota Press.

Deloitte (2012) Recognising RDR reality: The need to challenge planning assumptions. Available at: https://www2.deloitte.com/content/dam/Deloitte/uk/Documents/financialservices/deloitte-uk-fs-recognising-rdr-reality.pdf [Accessed 7th May, 2014]

Department for Business, Innovation and Skills (2013) The International Survey of Adults Skills 2012: Adult literacy, nmeracy and problem-solving skills in England. BIS Research Article No. 139. October, 2013. London. Department for Business, Innovation and Skills

Dixon (2006) Rethinking Financial Capability: Lessons from Economic Psychology and Behavioural Finance. London. Institute for Public Policy Research

Dunn, S. (2009) Six scandals from the darkest days of an already murky industry. The Observer online, $21^{\text {st }}$ June $2009 . \quad$ Available at: http://www.theguardian.com/money/2009/jun/21/financial-advisers-scandals [Accessed 7th July, 2014]

Edelman (2012) 2012 Edelman Trust Barometer: Executive Summary. USA, Edelman

Elliott, A., Dolan, P., Vlaev, I., Adriaenssens, C. and Metcalfe, R. (2011) Transforming Financial Behaviour: developing interventions that build financial capability. CFEB Consumer Research Report 01. July 2010. London. Consumer Finance Education Board FCA (Financial Conduct Authority) (2013a) Supervising retail investment advice: how firms are implementing the RDR. Thematic Review TR13/5. July 2013. London. Financial Conduct Authority.

FCA (Financial Conduct Authority) (2013b)Supervising retail investment advice: Delivering independent advice. March 2014. London. Financial Conduct Authority.

FCA (Financial Conduct Authority) (2014a) Retail investment advice: Clarifying the boundaries and exploring the barriers to market development. Guidance consulation. July 2014. London. Financial Conduct Authority

FCA (Financial Conduct Authority) (2014b) Developments in the distribution of retail investments: Purchasing investments without a personal recommendation or with 
simplified advice. Thematic Review TR 14/10. July 2014. London. Financial Conduct Authority

FCA (2015) Conduct of Business Sourcebook. Available at:

http://fshandbook.info/FS/html/FCA/COBS). [Accessed $12^{\text {th }}$ January, 2015]

FSA (Financial Services Authority) (2002a) Reforming Polarisation: Making the market work for consumers. Consultation Article 121. London. FSA.

Financial Services Authority (2002b), Polarisation: Consumer Research. London. FSA

FSA (Financial Services Authority) (2003) Reforming Polarisation: removing the barriers to choice. Consultation Article 166. London. FSA.

FSA (Financial Services Authority) (2006) Financial Capability in the UK: Establishing a Baseline, London, FSA

FSA (Financial Services Authority) (2007). A Review of Retail Distribution. Discussion Article 07/01. London. FSA

FSA (Financial Services Authority) (2008a) Retail Distribution Review. Feedback Statement 08/06. London, FSA

FSA (Financial Services Authority) (2008b) Consumer Responsibility, Discussion Article 08/5, London, FSA

FSA (Financial Services Authority) (2009a) Distribution of retail investments: Delivering the RDR. Discussion Article 09/18. London. FSA.

FSA (Financial Services Authority) (2009b) Delivering the Retail Distribution Review: Professionalism; Corporate pensions; and Applicability of RDR proposals to pure protection advice. Consultation Article 9/31. London, FSA

FSA (Financial Services Authority) (2010) Delivering the RDR: Professionalism, including its applicability to pure protection advice, with feedback to CP09/18 and CP09/31. Consultation Article 10/14. London. FSA

FSA (Financial Services Authority) (2015) RDR Library. Available at: http://www.fsa.gov.uk/about/what/rdr/rdr-library\#cp [Accessed $8^{\text {th }}$ August 2014]

Foucault M. 1970. The order of things. London. Navistock.

Fowler, S. (2011) Reforming the Financial Advice Market: Bridging the Gap or Widening the Chasm. London. Fowler Drew. Available at: http://www.fowlerdrew.co.uk/monkey/wp-content/uploads/rdr-research-articlejuly20111.pdf [Accessed 12th August, 2013]

Fundscape (2014) Navigating the post-RDR landscape in the UK: Assessing the potential impact of an RDR regime on the European fund industry. London. Fundscape.

Georgosouli, A. (2007) The debate over the economic rationale for investor protection regulation: a critical appraisal, Journal of Financial Regulation and Compliance, Vol. 15 No.3 pp.236-249

Goff, S. and Cadman, E. (2014) UK banks count climbing cost of PPI mis-selling. Financial Times online, $3^{\text {rd }}$ February 2014 Available at: http://www.ft.com/cms/s/0/8310b6ec-8ced-11e3-ad5700144feab7de.html\#axzz39ilDIrVS [Accessed $7^{\text {th }}$ July 2014] 
Hamilton, P. (2014) The blurred line between advice and information. Money Marketing, $28^{\text {th }}$ July 2014. Available at:

http://www.moneymarketing.co.uk/2012410.article?cmpid=pmalert_439364 [Accessed $11^{\text {th }}$ August, 2014]

Henriksen, L. F. (2013) Economic models as evices of policy change: Policy paradigms, paradigm shift, and performativity. Regulation \& Governance. 7, pp.481-495

House of Commons Public Accounts Committee (2009) Skills for Life: Progress in Improving Adult Literacy and Numeracy, Third Report of Session 2008-09. Available at:

http://www.publications.parliament.uk/pa/cm200809/cmselect/cmpubacc/154/154.pdf [Accessed: 17th January, 2013]

Hurman, N., and Costain, I. (2012) Researching The ‘Advice Gap’. March 2012.

Financial Services Consumer Panel. Available at: http://www.fscp.org.uk/publications/pdf/advice-gap.pdf [Accessed, 13th April, 2014]

Llewellyn, D. (1999). The Economic Rationale for Financial Regulation.Occasional Article No. 1. London, Financial Services Authority

MacKenzie, D. (2006) An Engine, Not a Camera: How Financial Models Shape Markets. Cambridge Massachusetts. The MIT Press

MacKenzie, D. (2007) Is Economics Performative? Option Theory and the Construction of Derivative Markets. In Mackenzie, D., Muniesa, F. and Siu, L. Do Economists Make Markets: On the Performativity of Economics. Princeton. Princeton University Press.

Mackenzie, D., Muniesa, F. and Siu, L. (2007) Do Economists Make Markets: On the Performativity of Economics. Princeton. Princeton University Press

MacKenzie, D. (2009) Material Markets: How Economic Agents are Constructed. Oxford. Oxford University Press

Moore, J. C. (2007) General Equilibrium and Welfare Economics: An Introduction. Berlin. Springer.

the Money Advice Service (2011) The Money Advice Service Launches To Give Free, Unbiased Advice To All. Press Release, 4 ${ }^{\text {th }}$ April, 2011. Available at: https://www.moneyadviceservice.org.uk/en/static/money-advice-service-launches

[Accessed 11th July, 2013]

the Money Advice Service (2013) The Financial Capability of the UK. November, 2013. London. the Money Advice Service

the Money Advice Service (2014) About us. Available at: https://www.moneyadviceservice.org.uk/en/static/about-us [Accessed 17th July, 2014]

Muniesa, F., Millo, Y. and Callon, M. (2007) An introduction to market devices. In Callon, M., Millo, Y. and Muniesa, F. (eds.) Market Devices. Oxford. Blackwell Publishing Ltd.

National Numeracy (2014) Facts and Figures. Available at: http://www.nationalnumeracy.org.uk/what-the-research-says/index.html [Accessed 16th August, 2014] 
NMG Consulting (2014) The motivations, needs and drivers of non-advised investors. A qualitative research report. London. NMG Consulting.

OFT (Office of Fair Trading) (1999) The Rules on the Polarisation of Investment Advice: A report by the Director General of Fair Trading. London. Office of Fair Trading.

ONS (Office for National Statistics) (2010) Social Trends, No. 40, 2010 Edition. Available at: http://www.ons.gov.uk/ons/rel/social-trends-rd/social-trends/social-trends40/index.html [Accessed 17th July, 2014]

OECD (2013), OECD Skills Outlook 2013: First Results from the Survey of Adult Skills, OECD Publishing. Available at: http://dx.doi.org/10.1787/9789264204256-en

[Accessed 17th July, 2014]

OECD (2014) Economic Outlook 2014, May 2014. Available at: ) (http://www.oecdilibrary.org/economics/household-saving-rates-forecasts_2074384x-table7 [Acessed 19th July 2014]

The Personal Finance Society (2014) The RDR and Consumers: The public's views towards the retail investment advice market. February 2014. London. The Personal Finance Society

Personal Financial Education Group (2013a) Annual Report 2013: Making a Difference. London. PFEG

Personal Financial Education Group (2013b) Financial education's place in the new National Curriculum confirmed. $12^{\text {th }}$ September, 2013. Available at: http://www.pfeg.org/about-us/news/financial-educationper centE2per cent80per cent99s-place-new-national-curriculum-confirmed [Accessed $7^{\text {th }}$ July, 2014]

Preda, A. (2007) Where do analysts come from? The case of financial chartism. In Callon, M., Millo, Y. and Muniesa, F. (eds.) Market Devices. Oxford. Blackwell Publishing Ltd.

Redman, P. 2000. Introduction. In du Gay, P., Evans,J. and Redman. P. (eds.), Identity: a reader. London: Sage.

Reichmann, C. (2014) National IFA chief calls for end to advice 'middle ground' . Professional Adviser, $3^{\text {rd }}$ March, 2014. Available at:

http://www.professionaladviser.com/ifaonline/news/2331849/national-ifa-chief-callsfor-end-to-advice-middle-ground [Accessed 12th June, 2014]

Ring, Patrick. (2004) A critical analysis of depolarisation, Journal of Financial Regulation and Compliance, 12(3) pp.248-262

Ring, Patrick . J. (2010) Governance and governmentality: a discussion in the context of UK private pension provision. Economy and Society, 39:4, 534-550

Sandel, Michael J. (2012) What Money Can’t Buy. The Moral Limits of Markets. London. Allen Lane.

Sandler, R. (2001) Review of medium and Long-term Retail Savings. London. HM Treasury. 
Selnow, Gary. (2004). 'Motivating Retirement Planning: Problems and Solutions'. in Mitchell, Olivia, and Stephen Utkus. (eds.), Pension Design and Structure: New Lessons From Behavioural Finance. Oxford: Oxford University Press.

Thaler, Richard, and Cass Sunstein. 2008. Nudge: Improving Decisions About Health, Wealth, and Happiness. New Haven, Yale University Press.

Webb, R., Watson, D. Ring, P. and Bryce, C. (2014), Pension Confusion, Uncertainty and Trust in Scotland: An Empirical Analysis. Journal of Social Policy. Vol.43 Issue 3 pp.595-613

Wonderling, D. (2005) Introduction to Health Economics. Maidenhead. Open University Press 